\title{
Environmental Issues in Journalism Coverage at the Suara Merdeka Newspaper
}

\author{
Amirudin Amirudin ${ }^{1, *}$ \\ ${ }^{1}$ Department of Anthropology, Faculty of Humanities, Diponegoro University, Semarang - Indonesia
}

\begin{abstract}
This article was written from the results of the study "Practices of Multicultural Journalism in Suara Merdeka Newspaper". This article reveals how environmental issues are packaged in the news through multicultural journalism conducted at Suara Merdeka Newspaper. This article is based on the assumption that news production always involves actors who have their imaginations, and a number of images are exchanged in the process of contestation and negotiation. The image becomes an entity that connects some interests which are outside media into the newspaper. Through the ethnographic method, this study reveals the dynamics of the relationship between actors that occur behind news writing. This study found that environmental issues have been successfully included as themes that meet the criteria for enforcing environmental purification and at the same time, criteria of the environment commodification. In terms of economics, this theme has relevance to the importance of economic growth driven through the use of the environment without destroying itself. While in criteria of environmental purification, bringing the issue of citizen rejection to the plan a cement plant is same as carrying out the mission of reducing activities of environmental exploitation.
\end{abstract}

Keywords: local newspaper; environmental issues; conservation criteria; preservationist criteria; news production field.

\section{Introduction}

This research starts from the question of how environmental issues are covered in the process of journalism in Indonesian local newspaper, in this case, Suara Merdeka newspaper, in relation to the formation of cultural products in the form of news [1,2]. This research is a holistic study that focuses on the study of the dynamics of relations between actors (news people) news sources, journalists, coverage coordinators, executive editors, and editor in chief - on loading social realities related to environmental issues. This holistic study is intended to reveal how the images of each actor are contradicted and conversely absorbed in the news production process as a factoid that connects social reality or reality outside the media with the reality of the media.

Many studies that link journalism to environmental issues have been carried out. Among a number of studies include Fitryarin's study of News and Community Perceptions of the Environment in Local Print Media in East Kalimantan. Through content analysis, Fitriyani examines how local newspapers pay attention to environmental issues that occur around East Kalimantan [3].

In addition, Novenanto's research revealed the economic aspects of media politics in packing the Lapindo Mud case in Sidoarjo, East Java [4]. However, these two studies apparently only focus on how media represent the environment in news copies and do not reveal how the creative process is behind the stages of news production that involve ethical aspects and techniques that emerge dynamically. The dynamics that not only involve the contestation of political-economic interests between actors in the news coverage process but how a number of interests are solidly consolidated by actors in the production of news. So the news is the essence of the place where a number of images from various actors are consolidated.

Based on Bourdieu's perspective, this study is intended to reveal how news people, in producing environmental news, exchange images and relate them to reality outside the media, and accommodate a number of interests from various actors [5-7]. Some of these interests include the need to bring together the perspective of conservationism held by actors who are strong with economic capital in treating the environment on the one hand but also strong environmental preservation needs. While, on the other hand, the need to connect how the actors are strong in the perspective of preservationism - the environment must not be exploited for economic purposes, except only to fulfill subsistence needs $[8,9]$.

* Corresponding author: amditg@,yahoo.com 


\section{Methods}

This research was carried out to media people at Suara Merdeka Newspaper when covering specific cases about the planned establishment of a cement plant in the Kendeng mountainous region of Pati in the 2017 - 2018 reporting period. Using ethnographic methods, researchers revealed how the news production process dynamics occurred., through close observation and interviews with news people ranging from resource persons, journalists, coverage coordinators, executive editors, to editor in chief.

The number of informants were 25 persons, consisting of 20 news sources, 2 journalists, 1 coverage coordinator, 1 executive editor, and 1 editor in chief. For those I conducted some in-depth interviews and observations with using questions of description, contrast, and structural, to find the deep structure (their cognition) when they do some news production.

Based on the interviews and observations, I make taxonomic and domain analysis to find their worldviews related to the environmental issues.

\section{Results and Discussion}

Captions According to the news in Suara Merdeka newspaper that researchers read, initially PT Semen Indonesia (Persero) planned to build a factory in Sukolilo, Pati Utara, Central Java in 2009. Residents also feel that the development will cause damage in their neighborhood. Then, the residents held a demonstration and also sued PT Semen Indonesia to reject the construction. The struggle of the Sukolilo residents was not in vain, they won a lawsuit in the Supreme Court (MA) and PT Semen Indonesia canceled the development in the area. PT Semen Indonesia again planned to develop in the Kendeng Mountains region, but this time they planned to build a cement factory in Gunem Subdistrict, Kendeng Mountains, Rembang, Central Java. The construction has also obtained permission from the local government by issuing a Regent Decree Number 545/68/2010 concerning the Mining Business License Area (WIUP).

The conflict began when there was a clash between PT Semen Indonesia (Persero) and the residents of Kendeng during the laying of the first cement mine. According to residents' testimony, they had never been given information about the construction of a cement plant in their area. Even the Environmental Impact Analysis (AMDAL) document also not socialized to residents. Therefore, residents do not know the negative impacts that the development will cause if properly done. Then the residents of Kendeng again sued PT Semen Indonesia (Persero) to the Supreme Court (MA) for issuing environmental permits for karst mining activities and the construction of a cement factory. They included evidence against the Central Java Governor and PT Semen Indonesia (Persero) in the lawsuit.

The struggle of the Kendeng residents was continued with a quite astonishing action in front of the State Palace of Jakarta. Kendeng farmers staged a demonstration by painting their legs across the Merdeka Palace on March 2017. This then stole the attention of all Indonesian people, including President Jokowi.

This controversial demonstration invited sympathy from various community groups shown in various media in Indonesia. Seeing this, President Jokowi also formed a Strategic Environmental Assessment Team (KLHS) so that mining activities in the area did not cause environmental damage in the short or long term and recommended which areas should be mined and not mined. Jokowi also decided to stop the construction of a cement plant in Kendeng until KHLS was completed. The KLHS was regulated in Law No. 32 of 2009.

Based on the analysis of the actors in conflict in the media, it can actually be divided into two. First, those who agreed to the construction of a cement factory in the kendeng area with constant attention to environmental sustainability. They are referred to as having a not-sopuritanist view of conservationism on economic capital. Secondly, those who did not approve of the sling area were used as cement factories because they could damage the karst which endangers the survival of the environment in Sukolilo. They are called having a view of preservationism or environmental housing that should not be exploited for the purpose of economic interests. The difference between the two ideological criteria lives into the cognition of the news people in viewing and positioning the environment. Both of them also caused conflicts between actors to take place also in the process of news production.

Milton (1996) provides interesting observations on the presence of environmental issues in the era of globalization [10-12]. According to him, the production, consumption, and contestation of news is not just a product of globalization but also a response to globalization. At this point, the process of commodification and ideologization through news meets and shapes each other

Final capitalism, according to Milton, "can be involved in both the ideology of commodities and the commoditization of ideologies". Environmentalism as one form of ideology appears as a power that forms commodities, not just a passive object formed by the process of commodification in all lines of life that characterizes market globalization. In other words, what happens is not just "commodification of the environment", but also "the idea of environmental purification" [7].

Table 1. Informant's responses and reasons to the cement plant at Kendeng.

\begin{tabular}{|c|c|c|c|}
\hline Response & Reason & $\mathrm{f}$ & $\%$ \\
\hline agree & conservationism & $\mathbf{1 2}$ & $\mathbf{4 8 . 0 0}$ \\
\hline disagree & preservationism & $\mathbf{1 5}$ & $\mathbf{5 2 . 0 0}$ \\
\hline \multicolumn{2}{|c|}{ total } & 25 & 100 \\
\hline
\end{tabular}

Based on a close look at the news production process about the planned establishment of a cement plant in Kendeng, it shows more clearly how the process of 
commodification and purification of the environment meets. The criteria for the commodification of the environment represented by conservationists and the criteria of environmental purification represented by preservationism form each other so that it would be difficult to conclude that the "ideology of environmental purification" is dominating the public arena called the market, or conservationism has been conquered by the market - many reductions appear in various popular analyzes.

The reality in the field of news production is not that simple. The actors supporting the 'preservationism' criteria or vice versa the 'conservationism' criterion actors process interactively, influence each other, and on many occasions, they can veto each other.

Thus, the actors supporting the criteria for "commodification of the environment" and the criteria for "environmental purification" do not totally reach the whole practice in the arena of news production. For Bourdieu that in each domain implies the existence of different habitus [5]. However, not all actors of journalism have the same trajectory in accumulating cultural capital when entering or leaving a particular domain. That is, in a realm, the expressions of actors outside the core of the game emerge. There is no total incorporation, individuals still have a disposition built through the history of their own socialization outside the news production arena. Naturally, if the expression appears and actions that are in accordance with the structure of action in a field.

There, the contradiction becomes possible. An expression or action may not be in line with the criteria of conservationism or preservation criteria, but still present coloring the game pattern. More than that, refer to Turner which will be discussed in the following section, if the overall practice of actors in a realm is seen as a game then the game is actually a form of "cultural performance" which allows for a loosening of rules, improvisation, even contradictions [13].

The question is, if the practices and interactions undertaken by the actors outside the media occur so complex, then in the realm of news production whether the pattern of such conflicts is also reflected on the media stage. So what exactly is the anchor that combines everything? Why do actors volunteer to come into contact with one another in an arena that is limited by clearly different explicit or implicit criteria? If conservationism and preservationism, despite playing a large role played by news actors, do not dominate the game - so that it cannot be called a binding anchor, are there other anchor forms?

To answer these questions, this study utilizes field concepts and processual approaches to the dynamics of the news actors in the domain. In a game domain, FG Bailey in his classic work Stratagems and Spoils identified the existence of five main elements [13-15].

First, there are prizes or trophies pursued by all actors. Second, there are personnel or actors who play. Third, the existence of leadership, in the sense that there are main actors accompanied by a number of followers. Fourth, there is competition, in the form of confrontation and contestation to fight for the prize or trophy. Fifth, there is a jury or referee who determines the rules of the game and decides the winner. For Bailey, any political arena (formal and informal) can be explored using such a "game theory" framework.

Although at some point, we can see actors in the news production realm establishing cement factories has players fighting over a prize, many questions arise immediately, especially relating to the assumption that actors act rationally with cost-benefit calculations. These assumptions will certainly narrow the analysis of the case of economic calculations which will then downplay the role of other actors who are not risking economic benefits.

However, when the prize is understood not only as a material-economic benefit, we will be able to see that the actors - news sources from the pro and contra groups, journalists, coverage coordinators, implementing editors, and editor in chief - indeed they are pursuing a goal that makes them moved to play in the news production arena.

Victor Turner can complete Bailey's "game theory". For Turner, the game does not only involve competition to compete for the championship but also is a "cultural show" [13]. The actors who play not only want to find victory but sometimes the goal is the game itself because in the game it is possible to have a social space to "play with" flexible rules and cultural constraints. That is if the game "championship" fights for a winning cup then the game "show" aims to gain pleasure in running the game itself.

The news production practices in the case of the planned establishment of a cement factory show how these two forms of play can appear together. For some editorial elites, the "prize" pursued of course is the amount of circulation, which in the world of media can be converted into financial figures [16-17].

Various actions and processes that some editorial elites live, can be traced as an attempt to win the quality of news products with a high number of readers. However, when pursued further on what qualities are considered to have high circulation, the news production team can only guess, can only mention the possibilities of a mixture of themes or the situation of society that lies behind the production of certain news.

The right mixture is considered to produce a high circulation. But the accuracy of the mixture can never be captured and formulated in its entirety, and when it is tried to be formulated it always misses - it always raises other possibilities, so that when the formula is applied or restarted, the results of the circulation that do not appear as expected appear. In the end, what happens is playing the mixes, playing a creative game in connecting trends, themes, and other elements. This creative game tends to be a more important goal pursued compared to the slippery and hard to catch circulation.

One journalist who does not appear to be pursuing a prize for economic benefits is actually pursuing another form of a gift. Meeting face to face directly with the resource person is a great gift they want to get. Shaking hands and talking directly to them has a value that is far higher than just economic value.

From ethnographic searches, it can be seen how they struggled to obtain these prizes. At some point, these 
nonmaterial prizes can be transformed into new currencies. The prize can be exchanged with other forms of value, including honor and prestige.

\section{Conclusion}

Returning to the original question, the anchor that binds various interactions in the news production process turns out to be more than one. Turner, on the one hand, stated that the realm of the game contained actors competing for the same prize. But on the other hand, he also acknowledged that in the game not all actors pursue prizes, but rather pursue the fun of playing itself.

Through this study, we can say one thing that there are indeed prizes being pursued by actors who play, but the form of the prize is more than one. Each actor has their own prize, which is not necessarily important for other actors. The variety of prizes are all neatly intertwined in one domain which acts as an action and interaction for the actors. That is what makes all actors able to play together in unity.

In that context, environmental issues became successful as a theme that met the criteria of environmental purification and at the same time the criteria for the commodification of the environment. From an economic standpoint, this theme has relevance to the importance of economic growth by utilizing the environment without damaging it. Meanwhile, in terms of environmental purification criteria, bringing the issue of siting residents to plans to build a cement plant is the same as carrying out a mission to reduce the negative impact of environmental exploitation.

Moreover, if the whole practice of actors in a show is seen as a game then the game is actually a form of "cultural performance" that allows actors to flex rules, improvisation, and even contradiction

At this point, Suara Merdeka Newspaper journalism shows its multicultural character, which is shown by an opportunity to make the arena of journalism a field of exchange and at the same time provide equal access for actors who, although ideologically different, between conservationism and preservation.

\section{Acknowledgement}

With the completion of the research and writing of this scientific publication, I would like to thank Prof. Dr. Yos Johan Utama as Chancellor and Dr. Nurhayati as Dean of the Faculty of Humanities at Diponegoro University, and also Editor-in-Chief of Suara Merdeka, who has given permission, support and facilitation for the implementation of scientific research and publications. Their support makes this scientific work come true.

\section{References}

1. M. Solihin, N. Kurnia, Pemaknaan Konflik Pabrik Semen Kendeng dalam Framing Media Berita online Kompas.com dan Suaramerdeka.com, Jurnal Ilmu Komunikasi 15(1), 16-27 (2017)
2. Suharko, Masyarakat Adat versus Korporasi: Konflik Sosial Rencana Pembangunan Pabrik Semen di Kabupaten Pati Jawa Tengah Periode 2013-2016, Jurnal Ilmu Sosial dan Ilmu Politik 20(2), 97-116 (2016)

3. F. Inda, Pemberitaan dan Persepsi Masyarakat tentang Lingkungan Hidup di Media Cetak Lokal Provinsi Kalimantan Timur, Jurnal Komunikasi Jurnal Ilmu Komunikasi 11(1), 17-29 (2013)

4. A. Novenanto, Mediated Disaster: The Role of Alternative and Mainstream Media in the East Java Mud Vulcano Disaster, MA Thesis in Department of Cultural Anthropology and Development Sociology. Leiden: University of Leiden (2009)

5. P. Bourdieu, The Field of Cultural Production: Eassys on Art and Literature, Columbia University Press. New York (1993)

6. A. Amirudin, .Jurnalisme Multikultural: Gagasan Mengembangkan Cara Pendekatan Pengkajiannya, Endogami: Jurnal kajian Antropologi 1(2), 94-103 (2018)

7. W. Mazzarella, Culture Globalization, Mediation, Annual Review of Anthropology 33, 345-367 (2004)

8. H. Nora., R.R. Wilk, The Environment in Anthropology: a Reader in Ecology, Culture, and Suistainable Living, University Press. New York and London (2006)

9. M. Kay, Enviromentalism and Cultural Theory: Exploring the Role of Anthropology in Enviromental Discourse, Routledge, London (1996)

10. S. Pane, Wild-ing the Ethnography of Conservation: Writing Nature's Value and Agency, Anthropological Forum 28(3), 217-235 (2018)

11. R.A. Harnanto, A.I. Ummah, E. Rekavianti, A. Ratnasari, Gerakan Masyarakat Kendeng, Rembang untuk Keadilan dan Penegakan Hak Asasi Manusia, Jurnal Sosiologi Walisongo 2(1), 1-16 (2018)

12. S. Panel, Framing the Loss of Solace; Issues and Challenges in Researching Indigenous Compensation Claims, Anthropological Forum 28(3), 255-274 (2018)

13. V.W. Turner. Dramas, Fields and Metaphors: Symbolic Action in Human Society, Cornell University Press. Ithaca. New York. (1974)

14. C. Travesi, Knowing and Being Know, Approaching Australian Indigenous Tourism Through Aboriginal and Non-Aboriginal Politics of Knowing, Anthropological Forum 28(3), 275-292 (2018)

15. J.P. Heiss, A Hausa Man Makes a Decision: A Contribution to the Anthropological Perspective on Decision-Making, Anthropological Forum 28(3), 236-254 (2018)

16. P.D. Giminiani. Who Owns the Water? the Relation as Unfinished Objectivation in the Mapuche Live World, Anthropological Forum 28(3), 199-216 (2018)

17. H. Purnaweni, Kebijakan Pengelolaan Lingkungan di Kawasan Kendeng Utara Provinsi Jawa Tengah, Jurnal Ilmu Lingkungan 12(1), 53-65 (2014) 